\title{
Schistosomiasis Mansoni in Bananal (State of São Paulo, Brazil). III. Seroepidemiological Studies in the Palha District
}

\author{
Fabiana Zacharias, Maria Esther de Carvalho/ ${ }^{+}$, Cybele Gargioni*, \\ Horacio M Santana Teles**, CláudioS Ferreira***, Valquíria R de Lima**
}

\begin{abstract}
Laboratório de Soroepidemiologia **Laboratório de Malacologia, Coordenação dos Laboratórios de Referência e Desenvolvimento Científico, Superintendência de Controle de Endemias, Rua Paula Souza 166, 01027-000 São Paulo, SP, Brasil

*Laboratório de Parasitologia/Setor de Esquistossomose, Instituto Adolfo Lutz, São Paulo, SP, Brasil ***Laboratório de Parasitologia, Instituto de Medicina Tropical, USP, São Paulo, SP, Brasil
\end{abstract}

The Palha district, municipality of Bananal, State of São Paulo, Brazil, had 10.3\% cases of Schistosoma mansoni diagnosed from 1994 to 2000 by coproscopy: about three times the municipality average. The immunofluorescent antibody test was used to assess gut-associated IgM antibody titers of samples from 452 inhabitants. It disclosed 129 (28.5\%) positive cases. Subjects were classified according to age, sex, birthplace, and period of residence. Titers varied from 8 to 4,096 (geometric mean: 170.2). Seropositives were aged from 6 to 69 years (average: 24.5), 75\% of them aged 34 or less, predominantly males ( 78 or $60.5 \%$ ). Of all subjects, $65.7 \%$ were born and had been living in Bananal since; $24.2 \%$ came from neighboring municipalities and are residing in Bananal from two months to 89 years (average: 22.7 years). Further Kato-Katz coproscopy from 97 seropositives (geometric mean titer, 619) revealed S. mansoni eggs in 11 subjects (11.3\%). Serology was deemed useful in screening subjects to be further investigated by coproscopy, considering that blood collection had better acceptance than supplying fecal samples. Higher than average serological titers may indicate new cases in endemic areas. Longitudinal studies associated with epidemiological investigation, including titer evolution are advised, as isolated data are difficult to interpret.

Key words: schistosomiasis mansoni - seroepidemiology - low transmission area - São Paulo - Brazil

In the State of São Paulo, Brazil, schistosomiasis mansoni has been reported in areas with low transmission characteristics, where prevalence, as detected by coproscopy has been changing since control activities sponsored by institutional programs were initiated, mainly by the year 1980. Most autochthonous cases are concentrated in two regions: Litoral (littoral) and Vale do Paraíba (river Paraiba do Sul valley) (Glasser 1995). Young people (aged less than 15) constitute $46 \%$ of the infected subjects and the pattern of acquisition of the infection shows a close association with leisure (Marçal Júnior et al. 1993), although there are also chances of adult infection associated with such professional activities as rice cultivation in low-lying areas (Glasser 1995).

Prevalence of the infection in the littoral has decreased, as assessed by stool examination, from $22.8 \%$ in 1980 to $3.3 \%$ in 1990 (Dias et al. 1992). Characteristically, stool examination reveal a predominance of low worm burdens, estimated as egg counts per gram (epg) of feces. As such results are based on the observation of only a few eggs per sample, chances of false negatives are high, and consequently prevalence data are underestimated (De Vlas \& Gryseels 1992). Aiming at increasing diagnostic efficiency, we started the use of the far more sensitive serological methods, which are already used elsewhere in

\footnotetext{
${ }^{+}$Corresponding author. Fax:+ 55-11-229.8292.

E-mail: esther@sucen.sp.gov.br

Received 18 June 2002

Accepted 15 August 2002
}

the State of São Paulo (Kanamura et al. 2002), in the valley of the river Paraíba do Sul (Kawazoe et al. 1981, Carvalho et al. 1997).

In the municipality of Bananal, situated in the river Paraíba do Sul Valley, schistosomiasis is transmitted according to the same patterns as observed in other regions of São Paulo: $2.7 \%$ positive fecal examinations, between 1999 and 2001 and, during the same period, an average epg of 67.33 by using Kato-Katz technique. However, in this municipality, the frequency of positives varied from $1.1 \%$ to $10.3 \%$ from 1994 to 2000 among districts (Teles 2001).

For this investigation we selected a sample of inhabitants of the Palha District, where the highest prevalences of schistosomiasis had been found, to estimate the distribution of serological results according to age group and gender. Serological tests are particularly useful when applied to screening cases of schistosomiasis in areas of low transmission. Such an investigation, due to the higher sensitivity of serological methods, requires smaller samples than fecal examinations, which are used yearly in the search for new cases.

\section{MATERIALS AND METHODS}

The serological survey was carried out during December 2000 in the Palha District (municipality of Bananal, State of São Paulo, 22040'44'S and 44¹9'08'W, Brazil). Blood samples, collected from finger puncture, were absorbed in previously standardized "Whatman \# 3" filter paper, according to Ferreira and Carvalho (1982), each $\mathrm{cm}^{2}$ of paper containing $15.1 \mu \mathrm{l}$ of serum. Written consent was obtained directly from the subjects involved or from those responsible for them in the case of children 
or the mentally handicapped, as currently recommended, according to ethical principles of the Helsinki Declaration regulating research which involves human beings (Conselho Nacional de Saúde 1996). While collecting blood, we obtained information concerning age, gender and time of residence in the area under study. Results were compared with those of stool examinations performed between 1998 to 2000 with the aid of the Fox Pro for Windows database and further analyzed by using Epi Info software (Dean et al. 1994).

The indirect IGM-IFATwas used to detect human IgM antibodies against gut-associated polysaccharide $S$. mansoni antigens (Nash 1978), prepared in paraffin sections of adult worms, as described elsewhere (Silva et al. 1992). For the determination of the geometric mean of reciprocal titers (GMRT) those previously positive at a 16 cut-off titer were submitted to titering.

By using the Kato-Katz technique (Katz et al. 1972), we searched for Schistosoma mansoni eggs in two fecal samples from serologically positive subjects.

\section{RESULTS}

IFAT revealed positive results for antibodies against gut associated anti-S. mansoni antigens in 129 samples $(28.5 \%)$ of the 452 collected. The distribution of the samples by age group and gender, and results of the test are shown in Table I. The proportion of positive tests was significantly higher in males $(P<0.01)$. Independently of gender, positive results can be found at the early age of 6 , a higher percentage having been observed in males. Seropositive subjects averaged 24.5 years of age, $75 \%$ of them aged 34 or less.

The distribution of titers of IgM-IFAT varied from 8 to 4,096 (GMRT equal to 170.2), distributed as a bimodal curve typical of a low-endemicity area (Figure).

Our sample included 297 (65.7\%) subjects native of Bananal and $109(24.2 \%)$ born in neighboring municipalities. About $10 \%$ of them had come from more distant municipalities. The period of residence of all subjects varied from two months to 89 years (average 22.7 years). Previous coproscopical results (from years 1998 to 2000) of subjects included in the serological survey of year 2000 showed that 323 negative serum samples, $92(28.5 \%)$ came from people who had never submitted fecal samples for examination; 214 (66.2\%) were negative for S. mansoni eggs and $17(5.3 \%)$ were positive for S. mansoni eggs. From 129 seropositives, 33 (25.6\%) had never submitted stools for examinations, $26(20.1 \%)$ were passing $S$. mansoni eggs and 70 (54.3\%) had negative coproscopy.

From 97 serologically positive subjects we collected stool samples, which, on examination, revealed that 11 of them were passing $S$. mansoni eggs (Table II).

We observed that GMRT of the serologically positive was 619 , while that of the five cases previously observed to be parasitologically positive was 891 .

\section{DISCUSSION}

In the Palha district, the distribution profile of IgMIFAT titers, when polysaccharide adult worm antigens are used, is typical of low endemicity areas and analogous to those found elsewhere in the river Paraíba Valley by Carvalho et al. (1997).

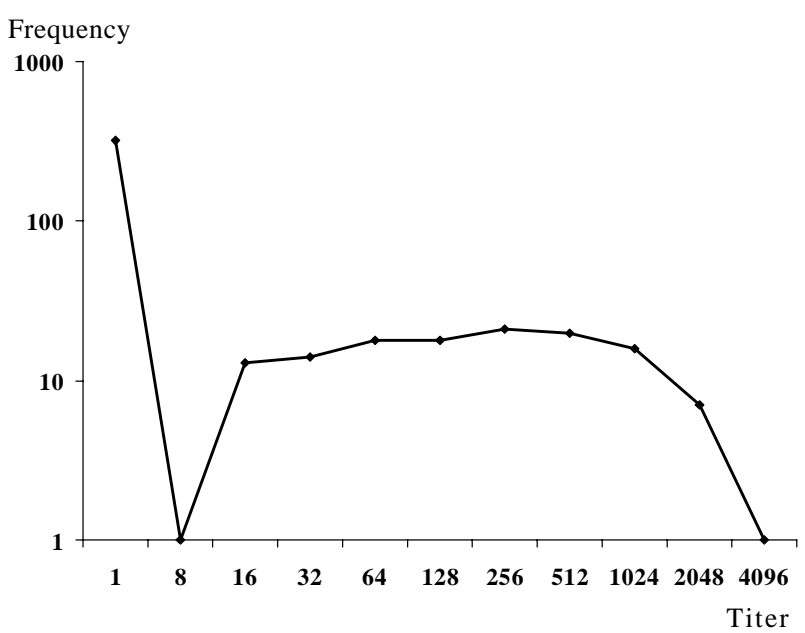

Seroepidemiology of schistosomiasis mansoni in the Palha district (Bananal, São Paulo, Brazil): titer distribution of IgM-IFAT antibodies against gut-associated Schistosoma mansoni antigens.

\section{TABLE I}

Seroepidemiology of schistosomiasis mansoni in the Palha district (Bananal municipality, State of São Paulo, Brazil, 2000): positivity within the sample studied

\begin{tabular}{|c|c|c|c|c|c|c|c|c|c|}
\hline \multirow{2}{*}{$\begin{array}{l}\text { Age group } \\
\text { (years) }\end{array}$} & \multicolumn{3}{|c|}{ Female } & \multicolumn{3}{|c|}{ Male } & \multicolumn{3}{|c|}{ Total } \\
\hline & Exam & Positive & $\%$ positive & Exam & Positive & $\%$ positive & Exam & Positive & $\%$ positive \\
\hline $1-5$ & 31 & 0 & 0 & 35 & 0 & 0 & 66 & 0 & 0 \\
\hline $6-9$ & 29 & 4 & 13.8 & 34 & 6 & 17.7 & 63 & 10 & 15.9 \\
\hline $10-14$ & 46 & 10 & 21.7 & 30 & 17 & 56.7 & 76 & 27 & 35.5 \\
\hline $15-19$ & 31 & 11 & 35.5 & 12 & 9 & 75 & 43 & 20 & 46.5 \\
\hline $20-24$ & 23 & 8 & 34.8 & 15 & 8 & 53.3 & 38 & 16 & 42.1 \\
\hline $25-29$ & 20 & 2 & 10 & 11 & 8 & 72.7 & 31 & 10 & 32.3 \\
\hline $30-34$ & 16 & 4 & 25 & 15 & 10 & 66.7 & 31 & 14 & 45.2 \\
\hline $35-39$ & 13 & 2 & 15.4 & 15 & 10 & 66.7 & 28 & 12 & 42.9 \\
\hline $40-49$ & 17 & 5 & 29.4 & 18 & 9 & 50 & 35 & 14 & 40 \\
\hline $50-59$ & 12 & 3 & 30 & 10 & 1 & 10 & 22 & 4 & 18.2 \\
\hline $60-69$ & 7 & 2 & 28.6 & 4 & 0 & 0 & 11 & 2 & 18.2 \\
\hline$\geq 70$ & 6 & 0 & 0 & 2 & 0 & 0 & 8 & 0 & 0 \\
\hline Total & 251 & 51 & 20.3 & 201 & 78 & 38.8 & 452 & 129 & 28.5 \\
\hline
\end{tabular}


TABLE II

Results of stool examination applied to seropositive cases in the Palha district, Bananal municipality, State of São Paulo, Brazil: some characteristics associated with Schistosoma mansoni detected cases

\begin{tabular}{|c|c|c|c|c|c|}
\hline Identification & Age (years) & Gender & epg (2001) & Previous exams results $(1998 / 2000)$ & IFT-IgM titer \\
\hline 1-DGA & 6 & M & 12 & $3, \mathrm{Al}, \mathrm{Tt}$ & 256 \\
\hline 2-LVV & 15 & M & 12 & $1, \mathrm{Al}, \mathrm{Tt}, \mathrm{Sm}$ in 1998 & 2048 \\
\hline 3-HEO & 37 & M & 12 & 2, Negativesn & 2048 \\
\hline 4-TSA & 13 & M & 36 & $2, \mathrm{Al}, \mathrm{Tt}, \mathrm{Sm}$ in 2000 & 256 \\
\hline 5-MP & 13 & M & 24 & $1, \mathrm{Tt}$ & 32 \\
\hline 6-IPM & 23 & M & 24 & 3, Tt, Sm in 1999 & 2048 \\
\hline 7-MARP & 18 & M & 12 & $2, \mathrm{Tt}$ & 4096 \\
\hline 8-MC & 26 & M & 12 & 2, Sm in 1999 and 2000 & 256 \\
\hline 9-SJNOS & 17 & M & 24 & absent & 512 \\
\hline $10-\mathrm{TC}$ & 21 & $\mathrm{~F}$ & 120 & absent & 256 \\
\hline \multirow[t]{2}{*}{ 11-JJS } & 23 & M & 60 & 1, Al, Tt, Sm in 1999 & 2048 \\
\hline & & & & & $\mathrm{GMRT}=619$ \\
\hline
\end{tabular}

epg: eggs per gram (of feces); Al: Ascaris lumbricoides; Tt: Trichuris trichiura, Sm: Schistosoma mansoni; GMRT among Sm cases: 891

Titers compatible with infection were found in children only 6 years old. Among adults, such values were more frequent in males. It should be mentioned that, according to local tradition, girls are expected to restrict their water contacts after menarche. They usually remain for a longer time at home, particularly after their usually early marriage. On the other hand, boys are subject to no restraints, having free access to contaminated waters. Most (75\%) of the infected inhabitants of the Palha district were aged 34 or under. According to Dias et al. (1988), people aged from 5 to 29 years are at the greatest risk. More recent serologic surveys often include only subjects aged under 17 (Camargo-Neves et al. 1998, Lima et al. 1998, Kamura et al. 1998). Silva et al. (2001) demonstrated that $62 \%$ of the inhabitants of the Palha district report contact with bodies of water, chiefly during such activities as bathing, fishing, and, to a lesser extent, extracting sand from the river bed. In most cases these are the motives for having contact with water contaminated with $S$. mansoni cercariae, in the municipality of Bananal, as described by Teles (2001). Such are the reasons for organizing a comprehensive survey, including most of the population of Bananal. We observed that the distribution of positive cases by age and gender are consistent with those inferred from the identification of eggs in fecal samples during the period from 1998 to 2000 .

The evaluation of serologic titer is indeed an important laboratory tool, as already mentioned by Shiff and Yiannakis (1976), who had observed a correlation between GMRT and age of greater risk concerning schistosomiasis. We observed higher GMRT values associated with positive fecal examinations than the overall average. Nevertheless, Lieshout et al. (2000) indicated that they found higher titers associated with non endemic areas than otherwise, but think serology is useful to investigate the incidence of scistosomiasis. Dias et al. (1971) had suggested the use of serologic methods for screening cases under close investigation by microscopy.

Filter paper for collecting blood samples obtained through finger puncture is adequate for investigation. In the Palha district it was accepted with less restrictions than supplying fecal samples. About $27 \%$ of the subjects included in this survey had never submitted fecal samples for examination, but approximately $25 \%$ of this group came out as serologically positive for schistosomiasis. Operational costs were lower than those of repeated fecal examinations involving the whole population (Silva 1992). Fecal examinations have well known disadvantages, as time consumption, false negatives, specially when worm burdens are moderate, and there are fluctuations in the elimination of eggs (Engels et al. 1996).

We suggest extending the serologic survey to other districts of Bananal, aimed at the most exposed age groups, followed by search for $S$. mansoni eggs in stools of serologically positive subjects. Moreover longitudinal serologic studies are recommended in this area, including a search for IgE antibodies to reveal any tendency to resistance to reinfection. Contrariwise to the opinion of Lieshout et al. (2000), even if serology does not identify all cases in an endemic area, (as we have also observed), this technique is invaluable for screening cases which difficult to investigate by other processes. Such techniques are adequate for Control Programs, which permit integration of different laboratories and standardizing equipment and reagents to obtain precise results.

\section{REFERENCES}

Camargo-Neves VLF, Gargioni C, Vellosa SAG, Kanamura HY, Dias LCS 1998. IgM antibodies to Schistosoma mansoni gut-associated antigens for the study of schistosomiasis transmission in Ribeirão Pires, São Paulo. Mem Inst Oswaldo Cruz 93 (Suppl. 1): 273-278.

Carvalho ME, Marques GRAM, Serpa LLN, Dias LCS, Kanamura HY, Delgado MR, Vellosa SAG, Gargioni C, Nascimento EMM, Zanardi A 1997. Evaluación serológica de la esquistosomosis mansónica en areas de baja transmisión del valle de Paraíba, Estado de São Paulo, Brasil, 1993 al 1995. XIII Congreso Latinoamericano de Parasitología, La Habana, Cuba, p. 113-114.

Conselho Nacional de Saúde (Brasil) 1996. Resolução no. 196, de 10 de outubro de 1996. 
Dean AG, Dean JA, Coulombier D, Brendel KA, Smith DC, Burton AH, Dicker RC, Sullivan K, Fagan RF, Arner TG 1994. Epi Info, Version 6: a word processing, database, and statistics program for public health on IBM-compatible microcomputers. Centers for Disease Control and Prevention, Atlanta.

De Vlas SJ, Gryseels B 1992. Underestimation of Schistosoma mansoni prevalences. Parasitol Today 8: 274-277.

Dias LCS, Camargo ME, Hoshino S, Ramos AS, Piza JT, Silva LC 1971. Inquéritos populacionais de esquistossomose mansoni por técnicas sorológicas de imunofluorescência e de hemaglutinação. Rev Inst Med Trop São Paulo 13: 37-44.

Dias LCS, Glasser CM, Etzel A, Kawazoe U, Hoshino-Shimizu S, Kanamura HY, Cordeiro JA, Marçal Júnior O, Carvalho JF, Gonçalez Junior F, Patucci R 1988. The epidemiology and control of schistosomiasis mansoni where Biomphalaria tenagophila is the snail host. Rev Saú Públ 22: 462-463.

Dias LCS, Marçal Júnior O, Glasser CM, Kanamura HY, Hotta LK 1992. Control of schistosomiasis mansoni in a low transmission area. Mem Inst Oswaldo Cruz 87(Suppl. IV): 233-239.

Engels D, Sinzinkayo E, Gryseels B 1996. Day-to-day egg count fluctuation in Schistosoma mansoni and its operational implications. Am J Trop Med Hyg 54: 319-324.

Ferreira CS, Carvalho ME 1982. Padronização de uso de papelfiltro como suporte de material para reações sorológicas. Rev Bras Malariol 34: 82-86.

Glasser CM 1995. Schistosomiasis control in the State of São Paulo. Mem Inst Oswaldo Cruz 90: 307-309.

Kanamura HY, Dias LCS, Glasser CM, Silva RM, CamargoNeves VLF, Vellosa SAG, Gargioni C, Lima VLC, Guercio VMF, Marques GRAM, Carvalho ME 2002. Estudo de anticorpos $\operatorname{IgM}$ para vigilância epidemiológica da esquistossomose mansoni em área de baixa endemicidade. Rev Inst Adolfo Lutz 60: 1-10.

Kanamura HY, Dias LCS, Glasser CM, Silva RM, Patucci RMJ, Chiodelli SG, Addis D 1998. Detection of IgM antibodies to Schistosoma mansoni gut-associated antigens for the study of the dynamics of schistosomiasis transmission in a low endemic area. Rev Inst Med Trop São Paulo 40: 225231.

Katz N, Chaves A, Pellegrino J 1972. A simple device for quantitative stool thick-smear technique in schistosomiasis mansoni. Rev Inst Med Trop São Paulo 14: 397-400.

Kawazoe U, Hoshino-Shimizu S, Correa NS, Silva LC, Pinto ACM, Camargo ME 1981. An immunoepidemiological study os schistosomiasis mansoni in Paraiba's Valley, São Paulo, Brazil. Rev Inst Med Trop São Paulo 23: 36-40.

Lima VLC, Guercio VMF, Rangel O, Kanamura HY, Dias LCS 1998. Immunofluorescent test on Schistosoma mansoni worm paraffin sections (IgM-IFT) for the study of schistosomiasis transmission in Campinas, São Paulo, Brazil. Mem Inst Oswaldo Cruz 93 (Suppl. 1): 283-288.

Marçal Júnior O, Hotta LK, Patucci RMJ, Glasser CM, Dias LCS 1993. Schistosomiasis mansoni in an area of low transmission. II. Risk factors for infection. Rev Inst Med Trop São Paulo 35: 331-335.

Nash TE 1978. Antibody response to a polysaccharide antigen present in the schistosome gut. I. Sensitivity and specificity. Am J Trop Med Hyg 27: 938-943.

Shiff CJ, Yiannakis C 1976. The use of seroloy by titering of fluorescent antibodies to evaluate levels of transmission of schistosomiasis in Rhodesia. Am J Trop Med Hyg 25: 427431.

Silva LJ 1992. A Esquistossomose Mansônica no Estado de São Paulo: Origens, Distribuição e Controle, Thesis, Faculdade de Ciências Médicas, Unicamp, Campinas, 140 pp.

Silva RM, Silva MIPG, Vellosa SAG, Kanamura HY 1992. Pesquisa de anticorpos IgM contra tubo digestivo do verme para o diagnóstico da esquistossomose mansônica. Rev Bras Pat Clin 28: 39-42.

Silva RA, Zacharias F, Carvalho ME, Teles HMS, Lima VR, Ferreira CS 2001. Schistosomiasis in Bananal (State of São Paulo, Brazil). IV: Evaluation of the risk to the human population of the Palha districty. 8th International Symposium on Schistosomiasis, Recife, ST2-17.

Van Lieshout L, Polderman AM, Deelder AM 2000. Immunodiagnosis of schistosomiasis by determination of circulating antigens CAA and CCA, in particular in individuals with recent or light infections. Acta Trop 77: 6980.

Teles HMS 2001. Estudo Parasitológico, da Transmissão e dos Impactos da Profilaxia da Esquistossomose Mansônica no Município de Bananal, Estado de São Paulo, Brasil, MSc Thesis, Instituto de Biologia, Unicamp, Campinas, 72 $\mathrm{pp}$ 